\title{
The Effect of Patient Satisfaction Levels on Competency and Facilities at Siti Khadijah Islamic Hospital, Palembang City
}

\author{
Sarikadarwati ${ }^{1, *}$ Henny Yulsiati ${ }^{1}$ Sandrayati $^{1}$ Susi Ardiani ${ }^{1}$ \\ ${ }^{1}$ Department of Accounting, Polytechnic of Sriwijaya \\ "Corresponding author. Email: sarikadarwati2610@gmail.com
}

\begin{abstract}
The purpose of the research is to improve human resources who build character as a concept of thinking about technology which is increasingly sophisticated. Where this also develops the stage of paying the hospital easily, namely the BPJS and the specific target to be achieved from this study is to analyze the Effect of Patient Satisfaction Levels of BPJS Health Users on Competence and Facilities at Siti Khadijah Hospital, Palembang City. The method used in achieving the target is descriptive and verification method of analysis using multiple regression methods for the first hypothesis and the second hypothesis is done by residual test. This research activity plan is started from literature literature study to compile a questionnaire as primary data and test the validity and reliability of the questionnaire. Furthermore, processing the questionnaire data (pre-testing) and improving the questionnaire. Distribution of questionnaires will be carried out on BPJS Patients at Siti Khadijah Islamic Hospital, Palembang city and sampling will be done by purposive sampling, where the authors determine certain criteria to be considered. After the data is obtained, it will be processed with SPSS to see the effect partially and simultaneously.
\end{abstract}

Keywords: Patient Satisfaction, Competence, and Facilities.

\section{INTRODUCTION}

Health services are one of the basic rights of society whose providers must be administered by the government as mandated in the 1945 Constitution Article $28 \mathrm{H}$ paragraph (1) "Every person has the right to live in physical and mental prosperity, to live, and to get a good and good living environment. healthy and have the right to obtain health services "and article 34" The state is responsible for providing adequate health service facilities and public service facilities".

Facilities are everything that is intentionally provided by service providers to be used and enjoyed by consumers with the aim of providing the maximum level of satisfaction. The Siti Khadijah Islamic Hospital in Palembang city provides facilities to the community to facilitate the community if they need the services of the Siti Khadijah Islamic Hospital in Palembang city immediately. Likewise, good service quality will certainly create satisfaction with service users. Siti Khadijah Islamic Hospital, Palembang, always tries to focus on customer satisfaction and responsiveness to every patient who comes and in providing health services using skilled and professional personnel so that the quality of service provided can meet the expectations of patients.

According to Law Number 40 of 2004 and Law Number 24 of 2011: The Social Security Administering Body or BPJS is an institution established to administer social security programs in Indonesia. Based on Law Number 40 of 2004 concerning the National guarantee system, BPJS is a non-profit legal entity (Depkes, 2013).

The hospital is required to always maintain the patient's trust by improving the quality of its services. In achieving the goal of patient satisfaction-oriented services, it is necessary to pay attention to things that play an important role in determining the perception of patient quality, including facilities, the role of doctors, medical personnel and nurses.

As for what happened at the Siti Khadijah Islamic Hospital in Palembang, it caused various phenomena. The phenomenon that occurs at the Siti Khadijah Islamic Hospital in Palembang city is obtained from the nursing committee that there are still complaints from 
patients, patient families about the dissatisfaction of services obtained from inpatient nurses such as the accuracy of administering medicines, administering injections, attendance of officers not on time and also nurses give less smiles and less attention to patients at the Siti Khadijah Islamic Hospital, Palembang. In addition, the treatment facilities have not met the standards, namely: there is still equipment that is not yet available, the environmental health requirements of the Siti Khadijah Islamic Hospital in Palembang city have not been fulfilled, the complaint service is not in accordance with the provisions.

\section{CONCEPTS AND THEORY}

\subsection{Competence}

Wibowo (2007: 324) states that competence is the ability to carry out or perform a job or task which is based on skills and knowledge and is supported by the work attitude required by the job. Henderson and Cockburn (in Absah, 2008) explain that competence is the company's ability and knowledge which is the basis for solving daily problems.

In order for the organization to easily achieve its goals, it requires the competence of leaders and competencies of employees / staff. According to Wibowo (2011) quoted by Torang (2014: 53), competence is "an ability (skill \& knowledge) to carry out or carry out activities / work / tasks. Competence is also an individual characteristic that underlies performance or behavior in an organization, a person's performance is influenced by knowledge, abilities, attitudes, work styles, interests and leadership styles".

\subsection{Service Facilities}

Facility is a means to facilitate and facilitate the implementation of functions. Facilities are individual components of the offering that can be easily grown or reduced without changing the quality and service model. Facilities are also a tool to differentiate one institution's programs from other competitors (Lupiyoadi, 2006: 150).

According to Tjiptono (2006), the design and layout of service facilities is closely related to the formation of customer perceptions. A number of types of services, perceptions formed from the interaction between customers and facilities affect the quality of the service in the eyes of customers.

Every company, especially in the health sector or hospital, has physical standards which include:

\section{Parking area}

The existence of parking lots in the hospital environment makes guests / patients comfortable.

\section{Lobby}

A place to wait for guests / patients to receive services from the receptionist or hospital staff.

\section{Rooms}

The main facilities for inpatients are usually a bed, a cupboard, a bathroom, a fan or air conditioning, etc.

\subsection{Patient Satisfaction}

Consumer satisfaction is the level of feeling where someone states the results of a comparison of the performance of the service product received and the expected one, Kotler in Lupiyoadi (2014: 228). Meanwhile, according to Kotler, who is quoted again by Fandy Tjiptono (2012: 312), consumer satisfaction is the level of a person's feelings after comparing the performance (or result) that he perceives compared to his expectations.

If customers say comfort is value, then the satisfaction they feel will occur when customers get comfort when using the product or service. If customers say the low price is value, the satisfaction they feel will occur when the customer gets a competitive price.

According to Irawan (2002: 40), customers are satisfied if their expectations are met. There are five main dimensions of customer satisfaction. The first dimension, is the quality of the product or service. Customers will be satisfied if after buying and using the product / service, it turns out that the quality is good. The second dimension is price. Sensitive customers, usually low prices, are an important source of satisfaction because they will get value form money. The third dimension is that service quality depends very much on three things, namely systems, technology and people. The fourth dimension is emotional factors. Customer perceptions play an important role because of the emotional value given by certain brands. The fifth dimension is the ease of getting the product or service.)

\section{RESEARCH DESIGN METHODOLOGY}

This study aims to determine the effect of BPJS Kesehatan user satisfaction levels on competencies and facilities at the Siti Khadijah Islamic Hospital in Palembang. In this study, the method used was a survey method, namely by using a questionnaire as the main data collection tool to take several samples from the population of this study. The population used is patients who use health services at the hospital.

\subsection{Research Place}

This research was conducted at the Siti Khadijah Islamic Hospital in Palembang City, which is located on Jalan Demang Lebar Daun, Pakjo Palembang. The object of this research is the behavior of the respondents 
which is manifested in patients at the Siti Khadijah Islamic Hospital between three constructs, namely the satisfaction of BPJS Health services, competence and hospital facilities.

\section{Research Variables and Operational Variables}

In this study the independent variables and the dependent variable will be used as follows:

1. Independent Variable: Competence and Hospital Facilities

2. Dependent Variable: BPJS Health Patient Satisfaction

In operational variables using indicators (questionnaires), where this will be used as a means of measuring BPJS Health Patient Satisfaction, Competence and Hospital Facilities which will later become evidence of research.

\subsection{Population and Sample}

The choice of sampling technique is intended to provide an overview of the existing population. This research was conducted from June 1, 2020 to June 12, 2020 using two levels of judgment sampling. Population taken as many as 150 patients.

The first stage, namely purposive sampling, is a sampling technique with certain considerations. The sample criteria in this study are as follows:

1.) Inpatients: Number of BPJS Kesehatan patients who were hospitalized at the Siti Khadijah Islamic Hospital in Palembang City at the time the patients were hospitalized in the period of June 2020

2.) Outpatients: Number of outpatient BPJS Kesehatan Patients at the Siti Khadijah Islamic Hospital in Palembang City when the patients were hospitalized in the period of June 2020

\subsection{Data collection technique}

The data collection techniques that will be processed are the results of the interview method and the questionnaire method that has been distributed, which will be distributed directly to patients at the Siti Khadijah Islamic Hospital, Palembang City based on inpatients and outpatients.

\subsection{Research Model Used}

The research model used in this study is multiple linear regression analysis for the first hypothesis. The multiple linear regression equation is as follows:

$\mathrm{Y}=\alpha+\mathrm{b} 1 \mathrm{X} 1+\mathrm{b} 2 \mathrm{X} 2+\mathrm{e}$

Information :

$\mathrm{Y}=$ Bound Variable (Dependent)

$\mathrm{A}=$ Constant b1b2 = Regression Coefficient

$\mathrm{X} 1 \mathrm{X} 2$ = Independent Variable

\subsection{Methods Used}

The statistical method used to test the hypothesis is multiple regression. This is in accordance with the formulation of the problem, objective and hypothesis of this study. Multiple regression method connects one dependent variable with several independent variables in a single predictive model.

\subsection{Research design}

From this study, it is expected to conclude that there is a fairly good significance regarding the level of satisfaction of patients using BPJS Kesehatan to the competence and facilities at the Siti Khadijah Islamic Hospital, Palembang City. It is also hoped that if the better the competence and facilities provided by the hospital, the better the patient's satisfaction will be, and vice versa.

\section{RESULTS AND DISCUSSION}

\subsection{Data Description}

In this section, the researcher will describe the results of the research and discuss the data obtained. The data is then processed first so that it can be analyzed and used for hypothesis testing. The research object chosen by the researcher was the Siti Khadijah Islamic Hospital, Palembang, which is located on Jl.Demang Lebar Daun, Pakjo Palembang. In this study, the distribution of questionnaires was carried out to the return of the questionnaires which required a period of less than one month.

The number of questionnaires collected was 95 or $96 \%$ of the total 100 questionnaires submitted. Thus, the number of questionnaires that can be processed is 95 questionnaires. The number of questionnaires that can be processed has exceeded 30, namely the minimum amount of data needed to obtain a distribution of measurement results close to normal. To analyze the data, researchers used the Statistical Product and Service Solutions (SPSS) for Windows version 25.

\subsection{Respondent Demographics}

Demographic data provides general information about the respondent's condition which can be qualitatively analyzed based on age, gender and occupation.

There are data of 90 respondents who were the object of the research, it can be seen that the respondents with the age level of 17-24 years amounted to 16 people or $17.8 \%$, the age level of 25-34 years was 27 people or $30 \%$, the age level $35-49$ years amounted to 15 or $16.7 \%$, the age group of $48-64$ years was 28 
people or $31.1 \%$, and the age group $>64$ years was 14 people or $15.6 \%$. From the number of respondents from the gender category, there were more male respondents, namely 56 people or $62.2 \%$ compared to only 34 women or $37.8 \%$. The type of work of each respondent based on the data above shows that the respondent works as a student / student as many as 5 people or $5.6 \%$, civil servants who dominate as many as 21 people or $23.3 \%$, private employees as many as 19 people or 21 , $1 \%$, as many as 20 workers or $22.2 \%, 15$ traders or $16.7 \%$ and not working as many as 10 people or $11.1 \%$.

\subsection{Variable Descriptive Statistics}

Descriptive in this study is presented to provide an overview of the characteristics of the research variables, including the minimum, maximum, mean and standard deviation values which are taken based on a distributed questionnaire.

It can be concluded that the mean (mean) score for the dependent variable Patient Satisfaction is 35.27 with a standard deviation of 35.27 , and for the minimum answer score is 29 and the maximum answer score is 40 . In the independent variable, the score for the average ( mean) Employee Competency is 31.00 with a standard deviation of 3.620, and for the minimum answer score is 24 and the maximum answer score is 35 .The score for the mean (mean) of the Hospital Facilities is 29.10 with a standard deviation of 3.554 , as well as for the score The minimum answer is 22 and the maximum answer score is 35 .

\subsection{Normality test}

The normality test in the regression model is used to test whether the residual value resulting from the regression is normally distributed or not. A good regression model is one that has a residual value that is normally distributed. This study used the KolmogorovSmirnov test statistical test to test the normality of the data with a significance level of $5 \%$. Residuals are normally distributed if the significance value is more than 0.05 .

The results of the One Sample KolmogorovSmirnov Test in the table above indicate that the residual probability ( $\mathrm{p}$ value) in this study has a value less than 0.05 , which is 0.027 . This means that the residual data are not normally distributed.

\subsection{Multiple Linear Regression Analysis}

Multiple linear regression analysis is an analysis to measure the amount of influence between two or more independent variables on one dependent variable and predict the dependent variable using the independent variable. This Multiple Linear Regression Analysis method is used to test hypotheses, as well as to see the strength of the relationship between Employee Competence (X1) and Hospital Facilities (X2) so it is necessary to test Employee Competence (X1) and Hospital Facilities (X2) on Patient Satisfaction (Y).

the results of multiple linear regression tests, it can be seen that the regression equation is as follows:

Effect of Patient Satisfaction $=11.435+0.528 \mathrm{X} 1+$ $0.257 \mathrm{X} 2+\mathrm{e}$

The explanation of the above equation is as follows:

- The value of the constant (a) is 11,435

This regression model has a positive constant value of 11,435 . The number 11,435 means that if the value of the employee competency variable with hospital facilities is 0 , then the value of the positive effect of patient satisfaction is 11,435 .

- The value of the coefficient (b1) is 0.528

This regression equation model has a positive coefficient value of 0.528 . the number 0.528 means that every increase in employee competence there will be an increase in patient satisfaction of 0.528 with the assumption that other independent variables have a fixed value.

- The value of the coefficient (b2) is 0.257

This regression equation model has a positive coefficient value of 0.257 . The number 0.257 means that every increase in Hospital Facilities there will be an increase in Patient Satisfaction of 0.257 with the assumption that other independent variables have a fixed value.

\subsection{Discussion}

\subsubsection{Employee Competence has a positive effect on Patient Satisfaction}

Based on hypothesis testing on the Employee Competency $(\mathrm{X} 1)$ variable, it has a tcount of 6.252 which is greater than the ttable of 1.662. For a significance value of 0,000 . From the research results, Ho is rejected or Ha1 is accepted. Therefore, it can be concluded that Employee Competence (X1) has a positive and significant effect on Patient Satisfaction (Y). Furthermore, based on the coefficient of determination (R2) of 0.368 or $36.8 \%$, while the rest is influenced by other variables not included in this study.

This shows that the Siti Khadijah Islamic Hospital in Palembang City, through the competence of nurses and doctors, plays an important role in the influence of patient satisfaction which in turn results in better patient satisfaction. As a good assessment of BPJS patients, it proves that when getting competent nurses and doctors, the patient gets satisfaction with the services provided and vice versa. 


\subsubsection{Hospital facilities have a positive effect on patient satisfaction}

Based on hypothesis testing on the Hospital Facility variable (X2), it has a tcount of 2.984 , greater than the $t$ table of 1.662. For a significance value of 0.004. From the research results, Ho is rejected or Ha1 is accepted. Therefore, it can be concluded that Hospital Facilities (X2) have a positive and significant effect on Patient Satisfaction $(\mathrm{Y})$.

Hospital facilities are proven to have a significant and positive effect on patient satisfaction. The results of this study are in accordance with research conducted by Tri Irfa Jarliyah Harfika, Nadiya Abdullah (2017) who found that hospital facilities had a significant effect on patient satisfaction. This means that the better the hospital facilities, the higher the satisfaction felt by patients at the Siti Khadijah Hospital, Palembang.

\subsubsection{Patient Satisfaction and Patient Trust have a positive effect on Service Quality}

Based on the simultaneous hypothesis testing, it can be seen that the F-count value is 25.344 and the significance is 0.000 . So, the F-count is 25.344> F-table 3.10. This means that $\mathrm{Ha}$ is accepted, so it can be concluded that simultaneously the independent variable Employee Competence (X1) and Hospital Facilities (X2) together have a significant effect on the dependent variable Patient Satisfaction (Y).

This shows that the Siti Khadijah Islamic Hospital in Palembang City, especially the nurses and doctors in it have implemented the principle of good service, namely Patient Satisfaction in hospital management. Employee competence at the Siti Khadijah Islamic Hospital in Palembang City consists of producing ability, kindness and integrity, so that nurses and doctors have high patient confidence in order to improve the quality of service to the maximum.

\section{FINDINGS AND CONCLUSIONS}

In this chapter the researcher will describe the results of the study and discussion of the data obtained. The data is then processed first so that it can be analyzed and used for hypothesis testing. The object of research chosen by the researcher was the Islamic Hospital of Siti Khadijah Palembang located on Jl.Demang Lebar Daun, Pakjo Palembang. In this research, questionnaires were distributed to the return of questionnaires that took a period of less than one month.

Based on hypothesis testing and discussion of research results, it can be concluded that the research results are as follows:

1. Employee competence has a positive and significant effect on patient satisfaction at the Siti Khadijah Islamic Hospital in Palembang City. This means that if the employee competence provided by the Siti Khadijah Islamic Hospital in Palembang is better, it can increase patient satisfaction, and vice versa.

2. Hospital facilities have a positive and significant effect on patient satisfaction at the Siti Khadijah Islamic Hospital in Palembang City. This means that the better the hospital facilities provided by the Siti Khadijah Islamic Hospital in Palembang City, it can increase patient satisfaction.

3. Employee competence and hospital facilities have a positive and significant effect on patient satisfaction at the Siti Khadijah Islamic Hospital in Palembang City. This means that the higher the level of competency of the staff and hospital facilities, the more patient satisfaction of the Siti Khadijah Islamic Hospital in Palembang City will increase, and vice versa.

\section{RECOMMENDATIONS}

Based on the above conclusions, further rekommendations can be proposed as follows:

1. For the Siti Khadijah Islamic Hospital in Palembang City, the results of the study show that in general patient satisfaction at the Siti Khadijah Islamic Hospital in Palembang City is quite good. this is because there are still some hospital nurses who are less professional in providing services to patients. For this reason, the Siti Khadijah Islamic Hospital in Palembang City should improve, complete and perfect the aspects that are considered still lacking by providing regular education and training to hospital nurses so that they can improve the competence of nurses at the Siti Khadijah Islamic Hospital in Palembang City. In addition, the Siti Khadijah Islamic Hospital in Palembang City should improve hospital facilities to increase patient satisfaction. For this reason, the hospital must overcome this by repainting the old building, so that the patient feels comfortable and the room, especially the treatment wall, is seen as clean. Some wheelchairs for patients should also be refurbished, because it can be seen from the patient that there is a rusted iron on the wheelchair.

2. For further researchers, the independent variables used in this study include only two independent variables, so there is still a need to study other independent variables outside of this research model.

\section{REFERENCES}

[1] Depkes. 2013. Dasar Pembentukan BPJS. Undangundang Nomor 24 Tahun 2011tentang Badan Penyelenggara Jaminan Sosial dan Undang-undang Nomor 40 Tahun 2004 tentang Sistem Jaminan Sosial Nasional, Pasal 5 ayat (1) dan Pasal 52.

[2] Kepmenskes RI Nomer 1204 Tahun 2004 Tentang Persyaratan Kesehatan Lingkungan Rumah Sakit. 
[3] Keputusan Menpan Nomor 63 Tahun 2003 Tentang Pedoman Umum Penyelenggaraan Pelayanan Publik.

[4] Kemenkes. Kepmenkes RI Nomor 44 tahun 2009, tentang Rumah Sakit. (Jakarta: Kemenkes RI. 2009).

[5] Kemenkes. Kepmenkes RI Nomor 82 tahun 2013, tentang Sistem Informasi Manajemen Rumah

Sakit. (Jakarta: Kemenkes RI. 2013).

[6] Murwansyah. 2012. Manajemen Sumber Daya Manusia (Edisi Kedua). Bandung. Alfabeta.

[7] Mongkaren, Steffi. 2013. Fasilitas dan Kualitas Pelayanan Pengaruhnya Terhadap Kepuasan Pengguna Jasa Rumah Sakit Advent Manado. Jurnal EMBA, vol. 1, No. 4. Manado: Universitas Sam Ratulangi Manado (1-11)
[8] Siagina, Sondang P. 2002. Manajemen Sumber Daya Manusia. Cetakan Ketujuh. Jakarta: Bumi Aksara.

[9] Sugiyono. 2014. Metode Penelitian Manajemen Cetakan Ke-3. Bandung: Alfabeta.

[10] Tjiptono, Fandy. (2005). Servatice Quality Satisfaction. Edisi Andi offiset. Yogyakarta.

[11] Undang-undang RI No. 36 Tahun 2004 Pasal 32 Tentang Hak Pasien 